\title{
Democracy Needs a Democratic Behavior
}

\author{
${ }^{1}$ Shamshad BiBi, ${ }^{2}$ Dr. Mussawar Hussain Bukhari \\ ${ }^{I}$ Department of Political Science, The Islamia University Bahawalpur, Pakistan Under the Supervision of \\ ${ }^{2}$ Associate Professor Pol.Science Deptt. The Islamia University Bahawalpur, Pakistan
}

\begin{abstract}
In this paper an effort has been made to look in to the real problems of the new democratic political set up and compare with the past governments. Restoration of democracy in Pakistan is a good sign. However common peoples not get its crop. Supremacy of ineffectual persons at each level and violation of rule of law spoil the democratic system. The government style in Pakistan lethargic, centralized, dominating definitely bureaucratic and feudalist. It can not keep up with the new technological age, which is extremely competitive. Lack of constructive education and democratic behavior are also major problems in Pakistan. Common peoples badly effected with extremely high price daily use things and high price electricity and fuel etc. Violation of merit, unemployment and harassment are major problems. The privileged of democracy made tall promises but after voted they betrayed and the peoples have lost trust in hideous system in the name of democracy. When our top leaders disobey the superior court and violate the rule of law. How we can expect the supremacy of rule and law at lower level. It is concluded that new coalition government would be a frail judged by any average. Like the other nations Pakistan also face many problems and challenges. We can improve and save democratic system with the help of constructive education, positive think and democratic behavior. Positive education raises the benefits of civic commitment. Democracy not only brings political freedom and human rights, but that it is also a driving force behind economic growth and development. If Pakistan takes sensible steps by making use of their constructive and positive ability democratic system will be able to safe and stable.
\end{abstract}

\section{Democracy Needs a Democratic Behavior.}

Democracy is a universal process of organizing political desires on an equal basis. That must be strongly entrenched in the belief and hops of the vast majority of a country to grow. ${ }^{1}$ Democracy is the assurance for the citizens that their affairs are going to be managed by a responsible government. For the truthful democratic system separation of powers, independence of judiciary, fair electoral process, accountability at each level and rule of law are vital basics. ${ }^{2}$ Democratic privileged should require developing group decision-making skills as a foundation for the democratic way. Too much power makes a man blind to reality. ${ }^{3}$ Democracy needs a democratic leader with democratic behavior. Democratic behavior is a learned behavior and democracy can be learned only by practice. It is possible when we see the perfection of their people and eager to increase an authentic sense of solidarity by others. Democratic process is the equal justice, stop poverty, respect of all citizens' and equivalent education at each level in a country. Here I refer a Chinas Philosopher advised if someone wanted to plan for a year, he should sow a seed; for 10 years, plant a tree; for 100 years, teach people. ${ }^{4}$ Democratic leader is truthful, courageous and capable and to take care of the poor. One thing remember here no any nations are found where one hundred percent honest and truthful politicians, like this all politicians and bureaucrats are not wrong. ${ }^{5}$ A major reordering of Pakistan's national priorities to contain, for illustration, massively larger investment in the countries educational in it's economy and in its democratic institutions, is no doubt desirable and compulsory. ${ }^{6}$ Democracy enables the safety of citizens through institutional safeguards impartiality before the law and the advancement of human rights. ${ }^{7}$ We should accept the crucial culture ethics which are really grown in humanity, like loyalty to family, respect and care of parents, care of neighbors, dedication to duty, truth, justice, honesty and hard work. Democracy has imported to the people their natural rights and freedom. ${ }^{8}$ All equal in the eyes of law whether they rich or poor, ruler or laborers. But unfortunately accountability only for lower level and on top level proudly violates the rule and law. In democratic system peoples are sovereign and power flows from the peoples of the leaders of government. The peoples are free to criticize and observe how these leaders perform. ${ }^{9}$ Not anything was out of sight from anyone relating to matters and policies to government. Democratic perform container be the linkage between peoples and their governments giving influence to root causes and grievances in a system. Which helps to address them resolve in turn give to the more successful consciousness of human maturity and human safety. ${ }^{10}$ In the mid-nineteenth century at becomes very apparent, while rulers and intellectuals were becoming more and more aware of the poverty of their societies and the weakness of their states, as contrasted with the wealth, power and aggressive self-confidence of the west. It's a time of closer contact with the west, during the study of language, educators and ever more military mostly attendance in Western countries. ${ }^{11}$ 


\section{Early Muslim History}

Now we traced the some historical facts to show how the principles of freedom, equality and deposition of rulers are operated in early Muslim history. History is full of incidents where the head of state remained sub judice to Qazi and answerable to public. The Holy Quran says, man should make for good but he creates for evil. The Holy Quran only mentions about a number of moral principles, which are relevant to political governance, and not about its fundamental principles and organizational structure. ${ }^{12}$ This suggests that people should decide political executive troubles on the basis of consultation among them, moreover they will entrust an able person with the task of resolving the problem. There is no model superior than democracy to kind things out in this way. The democratic idea is a religious idea in so far its starting point is the postulate that all men are endowed by their creator with certain natural rights; and for the protection of these natural rights, all men are to be treated as equal.

(In Surah Nuh: 21), The Quran denounces tyrants such as Nimrudh, Pharoah, Haman and others, but it is also dispraises those who follow tyrants obey their orders. This is why Allah dispraises the people of Noah by saying, "But they follow (men) whose wealth and children give them no increase but only loss." 13

The Prophet Hazrat Muhammad (SAWS) said, "When you see my nation fall victim to fear and does not say to wrong-doer, you are wrong," then you may lose hope in them. "So how about a regime that forces people to say to a conceited wrongdoer, "How just, how great you are. O our hero, our savior and our liberator!"

Another verse supports the rights of the accused.

"O You who believes, if a wicked person brings any news to you, you shall first investigate, lest you commit injustice towards some people, out of ignorance, then becomes sorry and remorseful for what you have done."(49/6.) Not all people who bring charges against other people are wicked. Nonetheless, everyone including the guilty is entitled to have any charges brought against them investigated and examined. ${ }^{14}$ When Hazrat Abu Bakar was selected as the first Caliph and said to the people "Obey me I obey the Lord and his Prophet, where in I disobey, obey me not.

Hazrat Ali (R.A) who appeared in a case of dispute with a jewish businessman, and off course nothing can be legislated against the Quran and Sunnah in our country. Now we see the another example, When Hazrat Umer (R.A) was elected as the new caliph, one of the companions of the prophet said to him, "Whatever the Caliph takes from the peoples, he takes it by law, and spends it by law. During the four Caliphs' period, the Caliphs frequently consulted Muslims as well as non-Muslims who lived alongside Muslims. ${ }^{15}$ When we compare with present they perform to serve their own interests, gaining means and supremacy. We must practice ourselves in the skills and sympathetic, which democracy requires.

Holy Prophet (PBUH) said "seek knowledge even if you have to go China" ${ }^{16}$ because knowledge is a light. It gives us awareness and positive think and it is a dignified profession.

As Allama Iqbal said, democracy is systems where people are counted not weight, in which heads are counted behavior and qualities, are not weighed. ${ }^{17}$ It is a great fault of this system in undeveloped countries like Pakistan where literacy rate is little. Lack of constructive education it makes our behavior positive and democratic according to the ethical values. Lack of awareness on all important matters is also a major obstacle in the way of democracy. Without awareness they can not express their own opinion and interest. How their political leaders and representatives use their powers. It's only possible when educated civil societies make efforts about their democratic rights and responsibilities and involve them in political life. The active role of civil society is most essential for democratic system. When we adopted the wrong system in which only people are counted how it can be possible we succeed in every field of life. In developed countries peoples are more responsive and well educated. They use their vote in accurate and optimistic way. Developed countries are more democratic but it is a one side of this picture other hand these countries use their power for their own interest and benefits. These countries make different deals for self power and other countries like Pakistan faced multidimensional problems at large scale.

\section{Pakistan Faced Multidimensional Problems}

In 1947, Pakistan came into existence as a parliamentary democracy.Democratic structure is a formation of government in which the power of rule is based on the will of stacks. Democracy aims at significant the connection stuck flanked by the supreme ruler and the piles in such a approach that ascendancy is assigned to the final. After sixty years of its existence as independence country democracy has remain a slight delusion in Pakistan. Democracy is a scheme of ascendancy in which the people prefer their representatives during elections. Their force deceit in the ballot box. If nation are not cautious and educated enough to make an enhanced alternative, the democracy will not thrive in that country. ${ }^{18}$

Let us now we evaluate the short constitutional history of Pakistan, since 1947 to 2010 and seek out the causes of failure.

1947 - 1956 Provisional Constitution. Sovereignty Conceptual 'Dejure' is Constitute Assembly. Governor General as sovereignty praxis 'Defacto' Philosophical interpretation, Hobbes, Schmitt notion of sovereign as 
exceptions. Agambens sovereign exist on point of indistinction. The constitution of 1956 stood for inherent uncertainty. A parliamentary federal form of government was adopted. The justification of controlled democracy appears relevant with Hobbes, idea of sovereign's rule of reason over the man of passions that make them imperfect and prone to harm themselves.

1958 - 1962 interim constitution under Martial Law, Sovereignty Conceptual 'Dejure' Chief Martial Law Administrator, sovereignty praxis 'Defacto' is also Chief Martial Law Administrator. Philosophical interpretation, Hobbes sovereign also Schmitt's sovereign of exception. Furthermore in 1958, he abrogated the constitution on his discreation believing of its being threatened by the political situation in the country.Once again Schmitt's notions of concrete indifference and irreducible particularly work here well.

$1962-1969$ Constitution of 1962 enforced on $8^{\text {th }}$ June. Amended eight times. Abrogated in March, 1969. . Sovereignty Conceptual 'Dejure' is President, sovereignty praxis 'Defacto' is also President. Philosophical interpretation, Hobbes, Schmitt, and Agamben's notion of suspension of rule. The year 1962, gave birth to a constitution which establish the government of the president by the president and for the president. The power to appoint and remove any judge was in president's hand.

1969 - 1971 Martial Law Provisional Constitution under the Legal Framework Order. . Sovereignty Conceptual 'Dejure' is President, sovereignty praxis 'Defacto' is also President. Philosophical interpretation, Hobbes, Schmitt, notion of 'sovereign power' Agamben's notion of continuous exercise of 'exception'become rule. In 1969, President Ayub Khan handed over his power to another military commander General Yahya Khan. In 1970, he issued a provisional legal framework order, only President can interpret this order and even the courts were not empowered to rule against the orders provisions.Here we see the monopoly over the final decision.

1972 - 1973 Interim constitution, Sovereignty Conceptual 'Dejure' Constituent Assembly, , sovereignty praxis 'Defacto' is also President. Philosophical interpretation, Transitional period. But close to Agamben's notion of exception as a ruler in country. Immediately after the war Zulfiqar Ali Bhutto, was both the president and the CMLA under the temporarily imposed interim constitution. It finally achieved a genuinely Federal Constitution.

1973 constitution Sovereignty Conceptual 'Dejure' is Legislature, sovereignty praxis 'Defacto' is Prime Minister, Philosophical interpretation, Schmitt's Commissarial dictatorship. President Zulfiqar Ali Bhutto was elected as the prime minister under the new constitution. Later by amendments the power of the judiciary was made limited.

1981-1985 Provisional constitutional Order 1981-1985, Sovereignty Conceptual 'Dejure' President, sovereignty praxis 'Defacto' is also President, Hobbes, Schmitt, 'sovereign authority' Agamben's notion of exclusion with inclusion of rule. After becoming the President and referendum in 1985, General Zia-ul-Haq proposed the famous eight amendments in the constitution of 1973. We easily compared Zias role in constitution making and extra gained powers with Hobbes sovereigne.

1999 - 2007 Interim Constitution under Martial Law \& Provisional Constitutional Order, Sovereignty Conceptual 'Dejure' is Martial Law Administrator as Chief Executive Officer, sovereignty praxis 'Defacto' Martial Law Administrator as Chief Executive Officer, Philosophical interpretation, Schmitt's notion of suspension of order and a situation of exception. Hobbes, Leviathan as all powers including military vested with discretion. General Pervez Musharraf proclaimed a PCO making himself the savior of the state and nation until 2007; he has proclaimed close to 22 amendments in the constitution of Pakistan.We can see the actions of sovereign in Pakistani context. ${ }^{19}$

2008-2010 Sovereignty Conceptual 'Hobbes, idea of sovereign's rule of reason over the man of passions that make them imperfect and prone to harm themselves. Dejure'is the President and self interest Parliamentarians. In 2010 President Asif Ali Zardari elected the President of Pakistan, and recently the parliament and the coalition parties positively passed $18^{\text {th }}$ amendment and the same was signed by the president which is a great success of the present government and the public of the Pakistan, after passing of the $18^{\text {th }}$ amendment the president peacefully transferred his executive powers to the Prime Minister so the present parliament again become the parliamentary system instead of presidential system but after passing of the $18^{\text {th }}$ amendment the Government face many kinds of difficulties like a "HAZAARA TEHREEK" and controversial system of appointments of Judges in the Supreme Court etc. so those controversial decisions become cause to clash with judiciary and other provinces. Basically the beneficiaries of NRO become a main reason of the 
present clash in-between different institutes in Pakistan. Here it is most needed that we evaluate the Current leadership with the past and seek out the main fault of this system.

In Pakistani context we can see the conversation revolves approximately different constitutional texts in order to locate the nature of 'sovereign power' in Pakistan. Repeatedly Constitutions were either abrogated around the nation of executive or legislative supremacy. Only is one Constitution 1973 said to be popular democratic. The strangulations of Constitutionalism fostered the culture of oligarchy among the power elite of every section of citizens. The abolition of the first constitution made the later constitutions vulnerable to similar onslaughts. Ayub Khan abolished the 1956 constitution and Yahya Khan scrapped 1962, constitution, drastic surgical procedure of the 1973, constitution by Zia-ul-Haq and Pervez Musharraf has imprecise both its democratic context and form. We can see that all these steps not according the democracy and damage the nature of true democracy. ${ }^{20}$ According to Saeed Shafqat, The armed establishment under Zia-ul-Haq invigorated the affiliation through spiritual privileges and the armed. Moreover conjugal factors, changes in external regional environment turmoil in Afghanistan, Soviet interference in Afghanistan stimulate the Islamic revivalist movement in Pakistan. There is considerable evidence how the United States and Saudia Arabia funneled finances, for mobilized to militant remuneration a war beside Soviet in Afghanistan. ${ }^{21}$ The political history of Pakistan is to visualize of the structure as manifesting the straight dominance of political influential of Pakistan. Who rule through the sufferance of the civil and military bureaucracy. The political privileged replaced but the power of the administrative system and the pressure of its officers is impervious to modify. Bureaucracy in Pakistan not only present as the main executive branch, but as the key legislative branch as well. ${ }^{22}$ For the foreseeable prospect, the army's vision's of itself its familial role, and Pakistan's tactical situation will be the mainly significant factors influential Pakistan's identity. ${ }^{23}$

Let we observe the role of US; in Pakistan at this instant we see the large scale American assist to dictators only for their own self interest and assistance. The Americans have tended to use their crucial financial and military support selectively against democratic governments. The US ongoing having problems with Pakistan when an elected government came to rule in 1972, but poured billions of dollars into the realm. While another military rule took over in 1977 and agreed to fight the Soviets in Afghanistan. ${ }^{24}$ In 1988-1999 had to live with a decade of US sanctions. In 1999 military regime of Pervez Musharaf remains a well supplied ally in the US war on terror. US sanctions for the period of civilian regime create the main obstacle in democratic process and unsafe for Pakistan and democratic system.

Now we turn the democratic period 1988, when Benazir Bhutto becomes Prime Minister 1988, and Ghulam Ishaq Khan becomes President of Pakistan. Differences arose between the P.P.P government and the Establishment. Benazir Bhutto's government ongoing in front of troubles on the political frontage. Ghulam Ishaq Khan appointed Benazir Bhutto as Prime Minister of Pakistan on the condition that she would offer full support to him in the Presidential elections. ${ }^{25}$ According to the deal Ghulam Ishaq Khan winning and securing the highest votes. Constitutional Amendments made by the R. C. O. and the Eighth Amendment that had given the President a great deal of power. The conflicts between the President and Prime Minister aroses in two areas, the appointment of the Military Chiefs and the Superior Court Judges. On August 6, 1990, President Ghulam Ishaq Khan exercised his supremacy through the controversial Eight Amendment of the Constitution. ${ }^{26}$ It is important to reminder that from 1988; elapsed those in rule could have started the Ehtesab process but failed because of their own individual desire of power and self interest. During the Benazir Bhutto and Nawaz Sharif period Pakistan constitution had been amended several times for the benefit of only the rulers not for common peoples. The country had suffered because of misrule. The situation had become very complex. During this democratic era both civilian governments failed to deliver. Matters had grown worse with time. ${ }^{27}$ Malfunction had been the norms and poor governance was the primary reason. Another reason was our leaders had no constructive vision for common people's welfare. Its fine example is our education system, and violence of merit and rule of law particularly at root level. The people have suffered because of the shortcomings of the political system. Throughout this time we can see the complete uncertainty in the ranks of the leadership. Here be noted that the rule of law places limits on the power of government. But when our leaders violate these limits then many hurdles and obstacles create in the way of democratic system and demolish the system. Firstly its duty of our leaders they must respect the law and reject fighting because democracy requires compromise but only on right option not on mistaken.

\section{Corruption}

Let us we explore the corruption story in Pakistani political system. The Pakistani nation is forced to have ignorant leaders, and we can say that corruption is the reflection of the behavioral patterns and social values of the world. We can define corruption in many ways; it has befallen joined at the hip element of our political culture. Corruption is one of the major obstacles to development and that its effects on progress are unfortunate. We can state that corruption also obliterate the spirit of maturity. It includes misuse of power, favoritism, nepotism, money and blackmailing, bribery and plundering the national assets and fiscal resources. 
Corruption is having a shocked effect on the country and on the largely economic expansion. The corruption surely leads to poverty, ethnic violence and other evil manifestation. Inside Pakistan civil military bureaucracy and extremely feeble selected institutions the Pakistani government has long been obvious by a lack of accountability. Both the development of the economy and firm political circumstances are being weakened by these factors. Common peoples face demands for bribes in their connections with government admittance vital public service's combination of excessive corruption and wretched beneath performance of state structure these days typify Pakistan. Corruption amongst the politicians had increased diverse with no accountability. The politicions don't take action against their fellow politicians, and in general elections a majority of landlords and capitalists win the elections through the authority of their baradries and affluence. Lack of fair accountability top to bottom destroys the moral values and destroyed people's confidence. When we analysis the periods of Ayub Khan and Yahya Khan's period we can perceive that Ayub Khan also brought massive industralisation and riches in the prosperous class. Resultantly corruption sneaks in bureaucracy and the members of Basic Democracies. Lastly he, ineligible well-entrenched politicians through the EBDO. Yahya Khan also unevenly fired up hundreds officers. Zulfiqar Ali Bhutto also send home hundreds senior officers in a very illogical manner and he also ended their constitutional guaranteed of service. For the period of democratic period of Benazir Bhutto PPP, and Nawaz Sharif ML-N both leaders dismissed as a result of corruption charges and accusation of power misuse. Benazir Bhutto's first term came to power in1988. Benazir Bhutto's policy of confrontation with the Punjab government kept the political situation unstable. Another major issue related to the dissolution of the Baluchistan Assembly on December 15, 1988. Further MQM formally joined hands with the combined opposition's parties against Benazir Bhutto's government. Another issue growing friction between the Benazir Bhutto and President Ishaq Khan related to the retirement the chairman of the joint chief of staff committee and the appointment of judges of the Superior Courts. Poor economic management, large scale corruption are the problems facing thr Pakistan. Bureaucrat independent elected President Ghulam Ishaq Khan dismissed her government. It is directed,

- against unconstitutional unlawfuland undemocratic practices.

- Against the policies of conflict, confrontation and obstinacy.

- Against the tendencies of opportunism, expediency and selfishness.

- Against the prevalence of rank corruption, incompetence and inaction.

- Against the growing apprehensions about the future of democracy;

- Against anti-democratic ways in the name of democracy and anti people practices in the name of populism. ${ }^{28}$

In October 1990, Islami Jamhoori Itehad led by Nawaz Sharif won the elections. During the Nawaz Sharif's first term he failed to close the great divide between the socio economic forces and the political system. Nawaz Sharif lost the support of MQM, and other side lost the trust of President Ishaq Khan. Throughout the Nawaz Sharif term law and order situstion in various parts of the country remained quite unsatisfactory. The cprruption in the civil bureaucracy and among political leaders although not new became more pervasive. The whole time the Nawaz Sharif's term NWFP and Balochistan remains as before a problem era. Growing crises between Ishaq Khan and Nawaz Sharif over a wide range of issue such as the controversial Eight Amendment and the fourth coming President elections. Tiff between Nawaz Sharif and Ishaq Khan in the arbitary action precipitated grave politico constitutional crises, and both President and Prime Minister resigned from their posts on July 17, 1993. Nawaz Sharif's government went the manner of its predecessor on similar charges of corruption, nepotism and maladministration. ${ }^{29}$

Under Nawaz Sharif's rule Pakistan's bureaucracy, police and public service were so infested with corruption and political favoritism and so starving of income that few Pakistanis probable any thing from government. Public reaction to the President's actions strong, and on 26 May, Supreme Court ruling restored Nawaz Sharif to power. Army Chief broked deal in which both left office. It was obvious that Nawaz Sharif's government was not incredibly effectual on key issues i.e. relations with the military and President and economic management alliance construction with MQM, and ANP, and he unsuccessful to make stronger the parliamentary democracy. Benazir Bhutto's government was replaced by Nawaz Sharif and his IJI party Islamic Democratic Alliance. During this period the confrontations intensified between government and opposition party. Benazir Bhutto allowed her husband to use her power; she gave a free hand to her husband Asif Ali Zardari to use her power for personal gain instead of improving the economy. It is needed to reminder that, a leader, politicians or officer of any field, who collect national wealth illegally, and use of power for self interest an example that involves Bribery, Abous of Power, Fraud, dishonesty and complicity.

The conflict shifted to the floor of the National Assembly. Pakistan's political history reflects a constant tussle among social groups for participation in or control of the political process. These conflicts may have affected economic decision making and consequently economic performance. The most disturbing issue in Pakistani politics in the confrontation between the PPP and it's revival the PML-N led by Nawaz Sharif. Numerous cases were brought against the family of Nawaz Sharif. The confrontation intensified between 
Benazir Bhutto's government and the Mian Nawaz Sharif's party. The PML-N responded by strikes shut down of business, wheel jamand protest meetings boyocate the assemblies.Benazir Bhutto was unable to control the perception of corruption at the highest levels of government and she failed to end her acrimonious confrontation with Nawaz Sharif. Benazir Bhutto's government was again dismissed by President Leghari in November 1996. The main charges against Benazir Bhutto's were wide scale corruption and extra judicial killings in Karachi. ${ }^{30}$ During the period till 1998, corruption ruined every one of its earlier records in all walks of life. Thousands of residential plots were prearranged to dominant politicians, bureaucrat's leisure of rules, trading of politicians became order of the day, gainful units were sold at rock bottom prices, thousands of jobs were given to the group lacking merit and loans to the jingle of billions were waived off freely. In here it's crucial to memorandum that Benazir Bhutto challenged her dismissal and the dissolution of the National Assembly in the Supreme Court, The Court upheld the President's actions and found her ousted government corrupt. Here question arises why our corrupt leaders again and again choice and grasp powers. Where is accountability and penalty for corrupt leaders and politicians? Where is rule of law and implementation on Courts orders? Is it democratic behavior of our elected leaders? All these wrong things damage the democratic process and it is against the spirit of democracy. Nawaz Sharif returned as Prime Minister but this time representing the Pakistan Muslim League party (PML). This era of democratic government ended in October 1999, following military coup led by General Pervez Musharraf. The Supreme Court validated Musharaf's claim to the Presidency in May 2000. During this regime Nawaz Sharif was sentenced for acts of terrorism although he was eventually pardoned and went into exile. Benazir Bhutto convited on corruption charges in Switzerland and home. ${ }^{31}$

March 9, 2007, General Pervez Musharraf removes Chief Justice Iftikhar Muhammad Chaudhary on charges of corruption. Further turbulence after dismissal of Chief Justice for alleged misuse of office. Chief Justice Iftikhar Muhammad Chaudhary challenges Pervez Musharraf's decision. ${ }^{32}$ Finally elections took place in February 2008; the parties formed a coalition government in March 2008 with a new Prime Minister Yousaf Raza Gilani. Pakistan again faced corruption is viewed as being equally pervasive within federal, provincial and local level. We can see the rapid decline in indicators for political stability. However all the country's indicators have collapsed. A stronger judiciary could surely help in bringing many corrupt individuals to the front and place them behind bars. Without fair accountability humanity resembles a pathway that has not repeatedly used and thorns and unsafe animals could be originated beside such pathway. Some users fall away as a result of painful experience all the time, making them therefore, becoming tired and weak and are forced to connect others on the wider path for possibility of continued existence. Bad effects of corruption in society we can see in many poor countries is not limited to the leaders, it is endemic and most damaging at lower levels in society where most of the citizens get more frustrated and they get more involved in different crimes.

\section{Deals Makes Flood of Problems in Pakistan}

Now we turn the culture of rampant political corruption has come in sharp focus for Pakistanis. How for self interest Senior British diplomat play active role under the deal with Musharraf. Like this deal these deals makes a flood of problems for our country. Musharraf has agreed to share power with Benazir Bhutto in that he takes over as a civilian President with Benazir Bhutto as the Prime Minister. The NRO, deal struck between Musharraf and Benazir Bhutto under pressure from Washington. ${ }^{33}$ President Musharraf and Benazir Bhutto are jointly seeking a way to the peaceful transfer of power from military to democratic rule. It is important to note that Benazir Bhutto's deal in 1988, between Benazir Bhutto and Ishaq Khan had its drop scene dismissal of Benazir Bhutto government. Zardari has been a beneficiary of this National Reconciliation Ordinance (NRO) $)^{34}$ which provides immunity to bureaucrats and politicians from corruption charges. Here question arise without deal it's not possible for Benazir Bhutto but immunity from corruption and murder charges to politicians and bureaucrats is its murky side. It is significant to reminder that an independent judiciary is compulsory for the correct implementation of a democratic system. However merit and truthfully accountability is essential. When all citizens have equal rights but when they always excluded and fails to be heard, it turn against democracy in anger and frustration. Now we turn the present government same pattern deals we can see Zardari with Nawaz Sharif on different issues. When deals formulate as a result of self interest over national interest it spoil the shape of political process. Misuse of political power creates many bad effects on a big part of society and selfish politicians unbalanced the country. It is crucial to note that how the character of justice and equality are trampled under the leaders they deal with. Our leaders forget fraud, favoritism, bribing, commission game and rigging devices running in the elections and injure the figure of democratic system. The initial thing the government should do is to keep this equilibrium and attempt to formulate all nations pleased. ${ }^{35}$ If we observed around us we can see that they should prefer education for the people first. The quality and stability of democracy has depended on the constructive education. The past of various governments for collapse of implementing factual policies for education to all stacks on impartiality and quality basis. Now we analyze the performance of the present governments on education and its quality issues. It is highlighted by the media that around 140 parliamentarians hold a fake degree and half of them are facing cases 
in the court but election commission of Pakistan is unable to do anything because as per law the authenticity of degree can only be challenged either by the voters or opposing candidates. In reaction to the media reports Prime Minister Gilani urged the partlimentarians to collectively protect parliament, regardless of their political affiliations as the institutions was being maligned for the issue of fake degrees. Prime Minister Yousaf Raza Gilani as per the order of President Zardari not only supported the crook but also announced to award him a bus. ${ }^{36}$ The News Sunday, May 16, 2010 Common citizens protest and demand ouster all fraudulent degree holders parliamentarians. The protesters demand that those found guilty should be banned for life from all political and government positions. ${ }^{37}$ It is imperative to reminder that if our top leaders and parliamentarians have its attitude concerning fake degrees and not condemned this erroneous obsession what expectation with these leaders and how they can easily and daringly fooling the entire nation. When our policy makers and parliamentarians have fake degrees how they can perform enhanced for the nation and the peoples. Performance Social conflicts arise when governance process abortive to run clash sufficiently through genuine political dialogue, mechanisms for suitable decision-making and the rule of law. Like the past today government again faced the conflicts between Judiciary and President not only President but also involve other coalition parties on the issue of N.R.O. and appointment of the Superior Court Judges. In democratic system rule of law is a central factor in which the laws and procedures apply equally to every one nation. Present government disposed on restoring judiciary is long and complex. This movement was started by the lawyers, who took to the streets and made financial sacrifices. After this many other factions' workers, politicians and media and this movement turned in to a massive and powerful force. The print media was responsible for forming the public opinion and public emotions of the positive revolutionary change. During this movement the Army has played a very positive part in the entire movement. ${ }^{38}$ In sum we need to bring to light the truth that it was the cooperative efforts that made this victory possible. It served to bring to the people a combined wisdom and influenced their way of thoughts and knows if there is no justice then no social morals can perfume their functions. Every government would have to accept the supremacy of the constitution and independence of the judiciary. Present democratic government contemplation they restored the judiciary and exhibited respect for the decision of the Supreme Court relating to appointment of the judges. Other achievements like Haqooq-e-Baluchistan initiative and consensus on National Finance Award is operating through the cooperation of four provinces. All the chief ministers Syed Qaim Ali Shah, Nawab Aslam Raisani, Amir Haider Hoti and dear role of Punjab chief minister Mian Shahbaz Sharif for resolving the issue. ${ }^{39}$ Now let us see the $8^{\text {th }}$ amendment story after the long struggle President Zardari termed the signing of the bill as an important milestone that aimed at undoing the constitutional changes made by the undemocratic forces. It is important to note that again we can see the powerful role of opposition parties and specially role of Prime MinisterYousaf Raza Ghelani Nawaz Sharif and Shahbaz Sharif positive steps for the democratic process. The unremitting pressure on Zardari to forego his unrestricted powers unquestionably played a major role in compelling him to realize that time has come for him to give up his powers. ${ }^{40}$ Without the persistent campaign and stress it would never have been possible to get done the landmark task of making Zardari to agree to surrender his unrestricted authority. Here question arises these unrestricted powers are the gift of autocrat in the name of $8^{\text {th }}$ amendment why our democratic leaders not ended this at initial priority. Other side of this picture is that these corrupt political pundits are now securing their power by bringing their followers, partners and relatives into the government of bureaucracy. Today the corruption has spread through almost every department of government. ${ }^{41}$ It is significant to note down that the Pakistanis are brothers and should live in harmony but when crucial matters as language and employment are involved such statements are merely moral hopes. Opportunities for such services as education and financial matters require great improvement. When we evaluate the Zia-ul-Haq rule we can see the role of political parties PPP, IJI and MQM are also contributing nothing to the process of nation building and are instead contributing to the sharp regional, linguistic and political differences in Pakistan. When we compared to some other political parties MQM has certain advantages. Most of its leaders are well educated. It emerged from middle class. The performance of MQM is impressive and convincing. Weakness of MQM for all time violent and aggressive behavior. The controversy concerning like the murder of Hakeem Saeed etc. ${ }^{42}$ It is needed we assess the past, In 1989, provincial government undertook a house to house search for arms.During the 18 month of Benazir Bhutto government the ethnic fragility within Sindh continued to survive. On May 1990, the police search operation near Pakka Qillah. On March 1992, operation cleans up. March 1995, ethnic, kidnapping and sectarian clashes in Karachi. When we see all these events we can see that MQM demanded the withdrawal of cases against their leaders. ${ }^{43}$ During present period again target killings events in Karachi infringe the both,-parties,position.

Today again we can see the coalition MQM and PPP.$^{44}$ However the history of coalition government in Pakistan is not deep rooted and our experience is not pleasant. But now we see political maturity which requires to be developed in almost all the political parties. It is a good symptom of increasing political maturity is apparent in some political parties. The renaming of the NWFP as Pakhtoonkhaw has reignited the demand for more provinces. It is not good sign and now Hazara Division peoples came out of their homes to register their strong 
protest over losing their identity and becoming slaves of the Parkton's. Another harmful side is over a dozen peoples lost their lives during protest. Peoples express their grievances, because they know that they have no justice in this system. ${ }^{45}$ Today same thing we can see in the name of Provincial autonomy, change the name of NWFP and in Punjab Saraiki movement. These people have proclaimed their independent ethnic identity within Punjab. They have demanded that Punjab should be bifurcated and Sarikistan would be constituted. ${ }^{46}$ Now MQM, contributing to the sharp regional linguistic and political differences again. Always selfish politicians found many supporters in some cases which give advantage to a country may be applied in some cases. Pakistan a universal true Democratic country in which all people of Pakistan is equal stake holders. We all desire progressive and stronger Pakistan but this stronger Pakistan does not go through over centralization and anti province policies. We should pursue the main beliefs of equality, justice and brotherhood. It is imperative to note that democracy in any country draws its power from a variety of actors, however mainly notably aspects are concerned from the equally government and opposition that shape the governance in the country. Other thing is behavior of the politicians and the political leadership, both inside and exterior the rule that influence the institutional aspects of democracy more straight. ${ }^{47}$

\section{Present Government Faced diversity of Problems.}

Like the past current government of Pakistan pursues the same standard in addition to opposition, coalition parties blameworthiness past and Pervez Musharraf era for all sorts of harms. Actually present government and its coalitions unsuccessful themselves to adopt effective and light strategy measures to undertake with all the significant issues and crises. Present government was democratically elected but he has not a democratic. Solitary object basic be renowned that democracy is not bad but when we see the present system and wrong policies and monopoly of powers his basic makeup dictatorial and not democratic. Firstly it is essential to know about the idea of good governance relates to the superiority of the relationship among rule and the voter. Several elements control on good supremacy like rule of law, participation, consensus equity and transparent accountability etc. Participation of competent common persons in every field of life and fair accountability at each level top to bottom is crucial and Democracy is based on core two ethics. But when we assess the present system state power is used merely for the assistance of the privileged and does not guard society from the extremes of the influential. Corrupt mafias grow influence and destabilized public assurance in political structure, executive authority and judicial system. ${ }^{48}$ In Pakistan the feudal families retained have power over national affairs from beginning to end the bureaucracy and the armed forces. The political power of the feudal class is consequent from their economic power. While the political power enables them to combine and develop their economic power. This combination has given them control over national affairs and enables them to thwart democracy in maintaining their hegemony. At the present Pakistan faced assortment of problems like poverty, sectarianism, ethnic, terrorism and regional tribulations. For the removal of these problems awareness and tolerance is essential which are developed due to education in positive direction. As we all know the function of education in nation building. Unluckily education structure of Pakistan is facing strong criticism equally from general and global researchers. Despite of all previous national education policies present government seemed to be failed because of lack of interest and not accurately implementation and deceitful policies. Major reason of this collapse is most our leaders, army officers, bureaucrats and landlords all desire their generations to settle in western countries. They have their own mafia group. Positive change and awareness come with the education which will lead to an optimistic change in our behaviors. Pakistan is a democratic country there are no nation in the world that are more democratic than the Pakistanis. If they adopt the right and golden principles and moral values that drive from religion.

Let us see the harms middle class and inferior class in particular are face crisis. Deprived Pakistanis are these days bearing the force of increasing food, petroleum and gas prices power crises, water crises, sugar crises etc, much as the impact of "structural modification policies" Government is only concerned to clutch commission and some object like to which will generate by rental power project. If Iran is willing to supply us low-priced electrical energy then our government certainly has the task in hand. ${ }^{49}$ This is the time the Pakistani nation to stand up and take a decision in which direction they are going and which path they should adopt to see better and flourishing Pakistan. Peoples know that where there is unity there is always success. All Pakistanis should join in the course of bringing corrupt leaders, politicians, mullah's and army to judgment. Pakistan is a true democratic country and true democracy unites the entire human race under one banner without any kind of discrimination. Democracy did not prevail through corruption and power. One major tool is environment to influence to behave. Negative and positive environment too influence to change the attitude accordingly their act. $^{50}$

Therefore behavior depends on the character and environment. Changing human behavior requires constructive education. Social behaviors are the identity of the humanity. As we know not all the citizens are fully aware of the political scenario in their country. The universal stacks may not be aware of the political issues in society. This may result in people making incorrect choices in undeveloping countries during election. 
When the most important political and constitutional issues have been ignored, and corrupt leadership corrupt the system and corruption was taken by the roots and damage the democratic system. Today nation need security and economic prosperity for common people. But we can see in the name of democracy they are killing the true meaning of it. The blatant violation of rule of law on the part of civilian only. ${ }^{51}$ When money is exchange for a favor in violation of laws and rules. When society suffers from lack of accountability, and respect for law and the constitution. All this possible with the help of right and positive education and with the help of responsive manner among the society. Although if we prepared ourselves with positive education we change the environment by their dominant character. It is necessary improve literacy by revolutionary methods.

\section{SUMMING UP}

Its Pakistan bad luck that corruption not be controlled because Pakistan has been ruled of corrupt government. It has been sparked like a fire in every institution of Pakistan the reason is lack of fair accountability. Today once again all corrupt leaders trying to dupe the public again. They snivel truth on the other hand tell deceit. If we save our nation we should need a complete refurbish of our political system and the government. It's time we get up and change it. We should get ride of all corrupt officers in every field of life. Every corrupt keeps throwing dust in the eyes of the world at large. . They held responsible each other and be happy. Faith of the peoples has faultily broken in the states institutions. Lack of fair accountability, monopoly of powers, discretionary powers, low income and lack of transparency are main harms. The accountability institutions are failed because laws are not implemented in correspondence and fortitude. It is the only way we must fight for our right to education, right of freedom and our right to a corrupt-free society. Merely way that we can grasp influential and corrupt officers answerable. The gap between rich and poor is widening, unemployment and price hike is badly affecting everybody. Due to lack of accountability in all spheres of life we are drowning rapidly. It's not incorrect that dishonesty also kills the courage of improvement. Common peoples feel that rule of law only for common peoples of society and rich top leaders are out of the law. If the rule of law is broken there will be no democracy, no human rights and no public safety. Limiting government intervention is necessary. It is mainly basic that strictly priority should be implementing policies dealings with detection and punishment of corruption. Other than if we do not rise and connect by you and cooperatively to save our nation by sacrificing our self-interests. We should understand the entire unique guidance for life, beliefs, dealings and morals that democratic system won and prevailed and rule. In factual democracy the most honored of us is the mainly righteous. Let us we all play their positive role for the construction of our country. Until every people at each level not involved in fair practice there will be no change in a country. Constructive behavioral change is indispensable in every field of life. I end with these lines when a person involved in good and right practice then many others involved and collect together in support of achieve their objectives.

\section{References}

[1] Interview: "Democracy needs to be extended to all levels of governance" KDUN http:// www.kdun.org/1059/democracy-globalgovernance.

The News, 28 April, 2008.

[3] Herald, The Great Land Robbery, Kamila Hayt, The age of the vigilate, June 2008, vol. 39, No. 6, P. 27.

[4] A. Q. Khan, Pakistan's defective education,

[5] http://www.pakspectator.com/army-and-democracy-in-pakistan/

[6] According to Saeed Shafqat, , New Perspectives on Pakistan Vision For The Future, Oxford University Press, 2007, P. 377.

[7] Dawn, Sunday, June 17, 2007. Anwar Sayed, Wide Open to Abuse.

[8] Leadership and Human Behavior.http://www.nwlink.com/ donclark/leader/leader/leadhb.htm/

[9] Shahid Javid Burki, Pakistan Fifty Years of Nationhood, Vanguard, Books Pvt, Ltd. Lahore, 1999, PP. 176-177.

[10] Concepts of Leadership, http://www.nulink.com/ donclark/leader/leadcon.htm/

[11] The basic moral values concerning political governance are seen, in Quran to be limited mainly with two concepts, those of justice and consultation. For justice, for instance, see verses 4/58, 5/8, 6/153, 16/90, 38/26 in the Quran and for consultation see 42/38, $3 / 159,48 / 10,48 / 18,5 / 7$.

[12] http://www.meforum.org/216/why-turkey-is-the-only-muslim-democracy

[13] The Holy Quran, Tabar-a-Kal-la-zi, Parah No. 29, Surah Nuh- 21.

[14] http://www.submission.org/democracy.html

[15] Turkish Journal of International Relation, Vol.2, No. 3 \& 4, Fall \& Winter, 2003, P. 113.

[16] opcit, A. Q. Khan, Pakistan's defective education.

[17] Why Democracy does not flurishe? By. Munir Ahmad Khalili. www.munir-khalili-blogpost.com.

[18] Allen Megrath, The Destruction of Pakistan Democracy, Oxford University Press, New York, 1996, P.1.

[19] Arjumand Bano Saeed, The Problems of Soverign Power and the Changing Faces of Pakistani Constitution, In Pakistan Perspectives, Volume 9, Number 1, January-June 2004, Karachi, PP. 117-131.

[20] Ibid, PP. 117-131.

[21] Saeed Shafqat, New Perspectives on Pakistan Vision For The Future, Oxford University Press, 2007, P. xxxi.

[22] Charles H. Kennedy, 1987, P. 5.

[23] Stephen Philip Cohen, The Idea Of Pakistan, Vanguard Books, Pvt Ltd, Lahore, 2005,P. 97.

[24] Hasan Askari Rizvi, Civil Military Relations in Pakistan, Survival, 1998, Vol, 40, No. 20. PP. $96-113$.

[25] Hasan Askari Rizvi, The Military and Politics in Pakistan, 1947-1997, Sang-e-Meel Publications, Lahore, 2000, P. 270. 
[26] Ian Talbot, Pakistan A Modern History, Vanguard Books, Pvt, Ltd. Lahore, 1999, P. 287.See, Charles H. Kennedy, The 1990 General Election, in Pakistan, William L. Richter in Pakistan 1992, Westview Press, Oxford, 1993, P. 19.

Pakistan's Recent History. NRO'S Decision. http://www.seamonitors.org/id87.htm/

[28] Ghulam Ishaq Khan, Address to Nation and Dissolution Order" August 6 1990, P. 4.

[29] Asif Haroon, Muhammad Bin Qasim To General Pervez Musharraf, Sang-e-Meel Publications, Lahore, 2004, PP. 383 -386.

[30] Hussain Haqani, Pakistan Between Mosque and Military, Vanguard Books, Lahore, 2005, P. 242. Also see, opcit, Ian Talbot, P. 339.

[31] opcit, AsifHaroon,PP.395-

[32] http://en.wikipedia.org/wiki/Suspension_of_Iftikhar_Muhammad_Chaudhry\#March_9.E2.80.9312.2C_2007

[33] Pakistan's N.R.O. and corrupt Democracies of South Asia.http://www.emoiz.com/Pakistan-nro-and-corrupt-democracies-of-southasia.

[34] Dawn, Wednesday, 27, Jan, 2010.The News, Saturday, November 21, 2009. Zardari Altaf among NRO beneficiars.

[35] The News, May 14, Friday, 2010. Fake degrees discrediting Parliament, Parties, Gilani

[36] Asif Zardari, Nawaz Sharif \& Pervez Musharraf, The future of Pakistan.www.asifism.com/.../asif-zardari-nawaz-sharif-pervezmusharraf-the-future-of-pakistan.

[37] The News Sunday, May 16, 2010

[38] teeth.com.pk/blog/.../protest-against-fake-degree-parliamentarians. teeth.com.pk/blog/.../protest-against-fake-degreeparliamentarians

[39] The News, Special Edition, Power of "No" March 16, 2009.

[40] The Nation, December 12, 2009, Consensus over NFC Award.

[41] Pakistan, begging for revolutionary change.http://www.onlineopenion.com.au/view.asp? Article=10431\&page=0

[42] Iftikhar H. Malik, State and Civil Society in Pakistan, Macmillan Press Ltd, London, 1997, PP. 242-243.

[43] opcit.

[44] Saeed Shafqat, Civil Military Relations in Pakistan, West view, Press, USA, 1997, PP. $230-231$.

[45] Herald, May, 2010, Vol, 42, Number, 5, Umer Farook, A Province by Any Other Name. P.20. November, 2009.

[46] http:// waseb.wordpress.com/pages/8/

[47] M.Adil Khan, Democracy and Its Challenges.Unpanl.un.org/intradoc/group/public/.../un/unpano28465.pdf.

[48] Imtiaz Shahid and Memoona Shahid, An Advance Study in Pakistan Affairs, Advance Publishers, Lahore, 2007, PP.475-479.

[49] Heavy Load Shedding-Why Pakistani Government is not accepting the offer of Iran for cheapElectricity?http://www.pakistaniscandals.com/

[50] WhatisBehavior.http://members.tripod.com/

[51] Major Problems Facing Pakistan Today http://www.ilmkidunya.com

[52] Democracy or clutter in Pakistan http://www.ilmkidunya.com

[53] Decentralization Reforms in Pakisyan During Ayub and Zia Era www.macrothink.org/journal/index.php/...;artivles/.../1501

[54] Pakistan, begging revolutionary change http://www.onlineopenion.com.au/view.asp?article=10431 